\title{
The Stabilizing Effects of International Politics on Bilateral Trade Flows*
}

\author{
Benjamin E. Bagozzi, ${ }^{\dagger}$ Steven T. Landis, ${ }^{\dagger}$
}

February 15, 2012

\begin{abstract}
International trade volatility can do serious harm to a country's economic and political stability. Recent research suggests that international trade agreements can reduce such volatility by reinforcing extant trade commitments, improving transparency, promoting policy convergence, and strengthening investor confidence. Drawing on this logic, we posit that international political ties can also produce notable reductions in a country's export volatility. Specifically, we argue that diplomatic missions and military alliances signal lower discount rates, increase political transparency, and enhance issue linkages among trading partners. These enhancements in turn work to stabilize a dyad's export flows. To empirically test this argument, we use a gravity model to evaluate the effects of directed diplomatic relations and alliances on bilateral export volatility for over 150 countries from 1950-1999. Controlling for confounding variables and exploring a wide array of model specifications, we find that the establishment of diplomatic relations or alliances with a trading partner can significantly reduce a country's bilateral export volatility. These results provide robust support for our main hypotheses.
\end{abstract}

\footnotetext{
* Paper to be presented at the Midwest Political Science Conference, Chicago, 2012.

$\dagger$ Department of Political Science, The Pennsylvania State University. email: beb196@psu. edu and st1131@psu.edu
} 


\section{Introduction}

The past half-century of globalization has generated an unprecedented increase in international trade flows (Kose, Prasad and Terrones, 2003, 57). While the advantages to this process are many, the rise in economic openness that has accompanied globalization has also made countries more vulnerable to international economic volatility, and to trade volatility in particular (Rodrik, 1998; Mansfield and Reinhardt, 2008). Such instability is a major cause for concern. Indeed, research has shown that-through its contributions to import and price instability, low growth rates, unemployment, and civil conflict — trade volatility can and does cause serious harm to societies and states. ${ }^{1}$ These potential misfortunes have accordingly led many politicians and interest groups to sound the alarm against rising trade volatility. For instance, in a critique of rising Sino-American protectionism, one U.S. port official flatly stated that, "[t]he one thing that matters most in international trade is stability, or at least, lack of instability."2 More recently, German Minister of State Cornelia Pieper directly linked trade stability to global economic crises in stating that " $[t]$ he world economy is going through turbulent times, with the euro crisis exacerbating what is unfortunately an already difficult situation. In times such as these, stable trade relations [...] are doubly important."3 Chinese President Hu Jintao echoed these very sentiments in recent visits with Korean and Croatian leaders, stressing in both cases that China and its trading partners must respond to the current crisis by working to "maintain trade stability." ${ }^{4}$ Hence trade volatility is viewed as a serious threat to nation-states, and understanding how countries ameliorate the harms posed by this public bad has accordingly become a major line of inquiry among academics and policy-makers alike.

In this regard, scholars have recently recognized that international institutions possess a number of unique features that work together to shelter states from trade volatility (Mansfield and Reinhardt, 2008). Specifically, Mansfield and Reinhardt find that international trade

\footnotetext{
${ }^{1}$ See, e.g., Rodrik (1998, 1999); Kaminsky and Reinhart (1999); Quinn and Woolley (2001); Mansfield and Reinhardt (2008).

2“"Hong Kong Woos Washington State," Journal of Commerce, 23 March 1987.

3"Speech by Minister of State Cornelia Pieper at the Xth German-Korean Forum," 17 November 2011. < http: //www.auswaertiges-amt.de/EN/Infoservice/Presse/Reden/2011/111117-D-KOR_Forum.html>.

4"Chinese President Hu Jintao Meets with Croatian Prime Minister Sanader," Ministry of Foreign Affairs, People's Republic of China 20 June 2009. <http://www.fmprc.gov.cn/eng/wjb/zzjg/xos/gjlb/3155/3157/t572559. htm>. "Chinese President Hu Jintao Meets with this ROK Counterpart Lee Myung-Bak in London," Ministry of Foreign Affairs, People's Republic of China. <http://www.chinaconsulatesf.org/eng/xw/t556362.htm>.
} 
institutions-such as the GATT/WTO and preferential trading areas (PTAs)—reduce trade volatility by (i) constraining member-states from introducing new trade barriers, (ii) diversifying the composition of trade and foreign direct investment (FDI) flows, and (iii) increasing transparency in policy, expectations and trade standards and policy instruments $(2008,622)$. Drawing on this logic, we argue below that two forms of international political ties-alliance agreements and diplomatic missions_-exhibit a similar set of trade stabilizing qualities. Alliances are defined as formal military-security agreements between pairs or groups of states that commit members to provide military (defense, neutrality, or entente) ${ }^{5}$ support to other members in the advent of a military attack. We argue herein that alliance ties of these sorts reduce trade volatility by extending private traders' time horizons (and thereby encouraging deeper and more diverse trade and investment), lowering the information problems that exacerbate to trade disputes, and aiding in the settlement of existing disputes. Our second international political 'institution' of interest is the diplomatic mission, which we define as the formal establishment of diplomatic relations between countries at the level of chargè d'affaires, minister, or ambassador (Singer and Small, 1966, 1973). We theorize below that diplomatic missions reduce states' bilateral trade volatility by increasing transparency in trade-policy and business practices, serving as informal and auxiliary channels for trade dispute settlement, and providing pro-trade 'pressure-points' that constrain foreign leaders from (i) (re)enacting protectionist policies and (ii) engaging in opportunistic behaviors against foreign firms.

To test these arguments, we employ a gravity model of trade volatility to examine the effects of alliances and diplomatic relations on bilateral export volatility during the post WWIIera over 25,10 , and 5 year periods. We evaluate our models using a wide range of controls, random and fixed effects estimators, and alternate operationalizations of our independent and dependent variables. Our results are highly robust, and support our claims that diplomatic ties and alliances each independently reduce trade volatility. Specifically, we find that diplomatic missions can reduce a country's bilateral export volatility by up to $16 \%$ over a 25 -year period, while having alliance ties with a trading partner reduces a country's export volatility over a comparable period by as much as $13 \%$. In brief, these findings imply that international political

\footnotetext{
${ }^{5}$ For a detailed explication of these three alliance types see (e.g.) Long $(2003,539)$.
} 
ties have a large and consistent stabilizing effect on states' levels of bilateral trade volatility. Thus, even in the era of globalization, wherein scholars and pundits often claim alliances and diplomatic missions to be obsolete (Talbott, 1997; Heine, 2006; Haftendorn, 2011), international political ties continue to serve a critical role in the global political economy.

This paper proceeds in four parts. In the following section we draw upon the institutionaldesign literatures pertaining to (i) international organizations, (ii) alliances, and (iii) diplomacy in order to identify the causal mechanisms that we expect should enable alliance-agreements and diplomatic missions to enhance trade stability and reduce trade volatility, leading us to derive two key hypotheses thereof. We next describe the data, estimation model, variables, and research design that we use to test these two hypotheses. Our analysis section then presents several empirical tests of our hypotheses, interprets the substantive significance of the resultant findings, and subjects these findings to a battery of robustness tests. Finally, we conclude with a summary of our results and a discussion of their implications.

\section{Theory}

According to extant research, trade volatility harms countries through several interrelated channels. Perhaps most notably, volatile trade flows can significantly undermine a country's domestic economic stability. In this regard, trade volatility has been found to (i) threaten workers' employment and wages (Scheve and Slaughter, 2004), (ii) reduce firm profits and market competitiveness (Aizenman, 2003), and (iii) depress or destabilize economic growth (Rodrik, 1998, 1999; Quinn and Woolley, 2001; Kim, 2007). The latter effect-that of trade volatility on aggregate economic growth—has been found to be especially acute (Rodrik, 1998, 1999; Grimes, 2006). Indeed, in a multi-decade study of New Zealand, Grimes reports that "[a]pproximately half the variance in annual GDP growth over 45 years can be explained by the level and volatility of the terms of trade" $(2006,583)$, while others find that these adverse effects of trade volatility may be even more severe for developing countries (Blattman, Hwang and Williamson, 2007; Razin, Sadka and Coury, 2003, 302-303). Second, and in part as a result of its harmful economic effects, trade volatility can also increase civil conflict. Hereof, the harm done to growth, investment, and employment by trade volatility has been argued in 
turn to lead to increased social and distributional conflicts between groups and governments, especially in countries with weak domestic institutions (Rodrik, 1999; Miguel, Satyanath and Sergenti, 2008; Fiala, 2009; Hidalgo et al., 2010). Finally, because trade volatility increases uncertainty, it also threatens the profitability of international commerce, and hence, reduces the actual size of trade flows between countries (Mansfield and Reinhardt, 2008, 630). Thus, trade instability poses a multitude of political and economic threats to societies and governments.

The good news, however, is that number of international and domestic political institutions have been found to reduce trade volatility, or to safeguard countries against the dangers that such volatility poses. ${ }^{6}$ Regarding international institutions in particular, scholars have recently demonstrated that international trade institutions-specifically the GATT/WTO and PTAs-decrease the volatility of international trade. Here Mansfield and Reinhardt (2008) argue that these international institutions do so through three related mechanisms. First, trade agreements reduce future volatility in trade-flows by 'locking-in' states' existing trade commitments and deterring the erection of new protectionist barriers (Mansfield and Reinhardt, 2008, 626). Second, Mansfield and Reinhardt (2008, 626-629) note that trade-agreements increase policy transparency and promote policy convergence among member states, which they argue reduces trade volatility by stabilizing the expectations traders; providing these actors with clearer avenues for trade dispute resolution and settlement. Third, international trade institutions signal long-term predictability and low credit-risk environments to international investors (Mansfield and Reinhardt, 2008, 629). This in turn (i) reassures investors that governments will not engage in predatory behaviors, (ii) FDI flows, (iii) shifts FDI composition more towards vertical and export-platform FDI, and (iv) helps to diversify export portfolios; all of which decrease terms-of-trade and commercial-flow volatility (Mansfield and Reinhardt, 2008, 629).

We argue below that many of these trade-stabilizing features hold as strongly, if not more strongly, for two types of international political ties_-diplomatic missions and alliance agreementsas they do for international trade institutions. Indeed, diplomatic missions and alliances are often explicitly constructed for the purposes of enhancing trade and trade stability between member countries. Alliances, for instance, not only implicitly encourage trade flows and verti-

\footnotetext{
${ }^{6}$ Rodrik (1998); Adserà and Boix (2002); Bernhard and Leblang (2006); Mansfield and Reinhardt (2008).
} 
cal FDI (Mansfield and Bronson, 1997; Long, 2003), but also often (i) establish institutions to integrate the markets and political-military apparatuses of member countries, (ii) explicitly encourage economic cooperation among alliance members, and (iii) adjudicate political disputes (Long, Nordstrom and Baek, 2007). For example, in surveying one of the most comprehensive alliance datasets to date, Long and Leeds report to this end that "the Alliance Treaty Obligations and Provisions (ATOP) dataset reveals that 39 treaties, 18\%, either include articles requiring specific acts of economic cooperation (for instance, the removal of certain trade barriers) or include statements requiring general economic cooperation and/or declaring that commercial agreements will be negotiated in the future" $(2006,437)$. Thus, although alliances are primarily designed for security purposes, they often include intuitional features that promote economic cooperation and economic stability.

The evidence for diplomatic missions is even more pronounced. The very origins of diplomacy during the second and third millenniums BC were rooted in the coordination of trade and economic relations between ancient city-states (Cohen, 1999, 5-6). In more recent times, trade promotion has continued to be an explicit objective of foreign diplomatic missions (Afman and Maurel, 2010). More often than not, such missions house export promotion authorities, commercial services departments, or trade departments that, in conjunction with diplomatic missions themselves, "have been widely used to promote export activities of countries, with the goal of increasing export volumes, the number of firms that engage in export activities, the number of countries reached by domestic firms, and the diversification of those exporting activities in markets and goods." (Segura-Cayuela and Vilarrubia, 2008, 9). Consider for example the US State Department, which now lists its main operating strategies as including (i) "Promoting peace and stability in regions of vital interest," (ii) "Creating jobs at home by opening markets abroad," and (iii) "Helping developing nations establish stable economic environments that provide investment and export opportunities," (emphasis added). ${ }^{7}$ Hence, trade promotion is a central component to the U.S. foreign services, and anecdotal evidence suggests that this is also the case for a wide range of other countries including the United Kingdom, Canada, Germany, Australia, and Spain (Gil, Llorca and Serrano, 2008; Rose, 2007, 24-26). Accordingly, schol-

\footnotetext{
${ }^{7}$ Cited from <http://www.state.gov/r/pa/ei/rls/dos/436.htm>, and Rose (2007, 24).
} 
ars have recently begun to establish a causal link between diplomatic missions and increases in trade flows between countries (Rose, 2007; Gil, Llorca and Serrano, 2008; Segura-Cayuela and Vilarrubia, 2008; Afman and Maurel, 2010).

Moreover, both alliances and diplomatic ties generate a range of additional policy and security externalities that can increase trade and trade stability indirectly. Together with the explicit tools for trade stabilization outlined above, alliances and diplomatic missions thereby possess a veritable cocktail of treatments for trade volatility, and the harms that it causes. As we shall see, many of these explicit and implicit trade-stabilizing mechanisms parallel those found within international trade institutions as identified by Mansfield and Reinhardt (2008), while others are quite novel. What follows therefore is a more detailed explication of the evidence and causal mechanisms underlying the relationships between these two forms of international political ties—alliances and diplomatic missions—and trade stability.

\section{Positive Reinforcement Mechanisms}

Alliance agreements and diplomatic missions can reduce trade volatility through a number of positive reinforcement mechanisms. These mechanisms provide states and private actors with positive incentives to behave in manners conducive to trade stability. The first way that these institutions do so is by increasing policy-transparency and promoting convergence in states' trade-policy practices. As Mansfield and Reinhardt argue, "[t]ransparency and convergence in policy instruments reduce the volatility of trade flows by stabilizing the expectations of private traders" $(2008,629)$. Indeed, by reducing information problems and uncertainty—as well as by extending states' time horizons of interaction-improved transparency and policy convergence can give private actors positive incentives to both (i) deepen their interstate trade and investment commitments and (ii) maintain these commitments when uncertainty does arise. In turn, these processes help to ameliorate trade instability by underpinning inter-state economic exchange with trade and investment commitments that are less prone to capital flight and protectionist interests. There are a number of specific mechanisms in place that allow for such processes to arise between alliance members.

Security alliances, for example, are often explicitly designed to increase and stabilize trade between member-states. Many alliance-agreements are accompanied by interlinked economic 
and trade agreements that obligate alliance members to engage in various forms of economic cooperation such as trade integration (Long and Leeds, 2006). As argued above, economic agreements of this sort should directly increase trade stability between alliance-members by reducing the information problems and policy discontinuities that—when left unaddressed-can produce 'boom and bust' cycles of trade and investment (Mansfield and Reinhardt, 2008). For example, many alliance-agreements are accompanied by 'Defense Trade Cooperation Treaties,' which are designed to improve security among treaty-members by directly promoting cooperation through the facilitation of trade in military technologies and goods. These security agreements are often explicit in their intentions for promoting trade stability between members. For example, in providing a statement on Defense Trade Cooperation Treaties to the Senate Foreign Relations Committee, a U.S. Assistant Secretary for Political-Military Affairs plainly stated; "[w]e must recognize the economic and strategic importance of facilitating legitimate and secure trade between our nations. The Treaties help to accomplish this objective." 8 Thus, one way that alliances are able to harmonize and stabilize members' trade practices is by binding alliance members to economic agreements that foster deeper and more lasting trade-ties.

Alliance agreements also promote transparency and policy convergence through indirect channels. In addition to incorporating actual trade-agreements into their provisions, alliances often also create permanent organizations such as standing committees to alleviate informationproblems between member-states and require allied militaries to integrate and institutionalize their military activities and command structures for the purpose of coordinating defense and security policies (Long, Nordstrom and Baek, 2007, 1107-1108). These institutional accompaniments not only "crystallize norms and expectations of behavior among their members" (Duffield, 1992; Long, Nordstrom and Baek, 2007, 1104), but also help to stabilize trade flows between member-states by promoting transparency and reducing information problems in the arenas of trade policy and trade dispute settlement. This increased transparency and policy convergence directly reduces trade volatility by enhancing the ability of private traders to monitor foreign governments (Mansfield and Reinhardt, 2008, 629). Indeed, by serving as information focal points that credibly signal long-term security stability, alliances help to guarantee

\footnotetext{
${ }^{8}$ Statement before the Senate Foreign Relations Committee Washington, DC December 10, 2009. http://www. state.gov/t/pm/rls/rm/133366.htm.
} 
future cross-national capital investment returns, thereby stabilizing future investor expectations and any resultant trade flows. Moreover, security policy coordination devices often spill-over to other policy areas, and foster the development of deeper and more secure trade-ties by increasing the probability of future cooperative agreements between alliance-members—such as defense trade cooperation treaties mentioned above. In the event that trade disputes do arise, integrated security apparatuses - and the transparency and policy convergence that this integration gives rise to- can provide governments and private actors with additional informationalresources and political pressure-points for seeking a cooperative outcome, which again has been found to reduce trade volatility (Mansfield and Reinhardt, 2008, 629). That is, an increasing web of cooperative ties helps to increase economic stability by reducing information asymmetries and raising the costs of defection. Thus, the transparency and policy convergence that alliances promote together help to (i) stabilize trader expectations, (ii) deepen trade ties, and (iii) promote successful (trade-)dispute settlement. These three qualities in turn reduce trade volatility between member states.

Formal diplomatic ties can engender a similar set of positive reinforcement mechanisms. Either independently or through the trade-promotion and intelligence services that they often house, diplomatic missions extensively gather 'on the ground' information on a host-country's business practices and political-economic peculiarities. This information is then disseminated to home-countries' governments, firms and investors through private consultations with domestic firms and publicly available country reports. Such practices exist to provide industries and international entrepreneurs with technical and market expertise about a foreign country's laws and regulations as well as to assist these private actors in both (i) navigating the nuances of existing trade agreements and (ii) seeking recourse when these agreements are violated. Indeed, as as Segura-Cayuela and Vilarrubia note, "The most repeated justification for the role of international promotion activities is that of imperfect information...In this case, promotion activities may help eliminate, or at least, reduce these uncertainties that abound in both sides of the market" $(2008,9)$. Through such services, diplomatic missions thereby enhance bilateral-trade transparency by reducing the informational challenges that firms often face when navigating (i) the politics of foreign governments and (ii) the legal requirements of any existing trade 
agreements. With these information problems abated, there will be less uncertainty and more predictability surrounding trade and investment in a country housing a diplomatic missions from a given home country. These features will in turn stabilize the price of traded goods and deepen the commitments of international investors.

Diversification represents a second channel of positive reinforcement through which alliances and diplomatic missions work to improve trade stability. In many countries, one of the major causes of trade volatility is a reliance on single outputs or commodities for trade (Blattman, Hwang and Williamson, 2007), and hence diversifying exports is one way for a country to overcome its sensitivity to trade volatility (Mansfield and Reinhardt, 2008, 629). Similarly, increases in FDI flows, and the diversification of such flows towards vertical and export-platform FDI, helps to reduce the volatility of a country's trade flows by encouraging less risky, long-term international investment that (i) is less likely to flee countries in the event of a financial panic and (ii) gives international investors a stake in seeing a host-country's government resist protectionist policies (Mansfield and Reinhardt, 2008, 629). As we shall see, there are several features by which alliances and diplomatic ties help to encourage trade and FDI diversification, and hence, trade stability.

Alliances not only increase trade and investment through security externalities (Mansfield and Bronson, 1997; Long, 2003), but also help to diversify these economic flows Mansfield and Bronson (1997, 95). FDI diversification, for example, can arise due to alliances' abilities to extend private actors' time horizons of interaction. Alliances are costly signals by membergovernments as to the durability of their relationship(s). Investors and industries know that by signing onto an alliance, states are committing to help one another in times of crisis, which signals to domestic private actors that alliance-members' markets are likely to exhibit long-term stability to the extent that these commitments hold. Hence, alliances communicate long and stable time horizons of state-to-state interaction to investors, thereby prompting these actors to want to invest more, and more deeply. In essence "defense pacts provide information to firms seeking to establish commercial exchange relationships that are less likely to be hindered by conflict in the future; firms realize that a state with allies promising to defend it is likely to to be attacked. If defense pacts deter attack by a challenger, firms should use this information in 
making decisions to establish trade. In the event the ally is attacked, a firm's own government is obligated by the alliance treaty to protect the trading relationships of its firms" (Long, 2003, 542-543). State-level commitments-to-continuity such as alliances are in turn argued by (Mansfield and Bronson, 1997, 95) to encourage more relation-specific and vertacalized FDI between alliance members, and hence more FDI diversification. Relation-specific or verticalized FDI are long-term investments, and therefore are pursued by investors only if their investments can be guaranteed in the future. Alliances increase the likelihood that such an investment can be guaranteed by signaling to investors that the relationship between a home country and host country is stable and lasting Mansfield and Bronson (1997, 95). In doing so, alliances promote diverse and stable investment, which protects alliance-members against trade volatility.

Diplomatic corps also contribute to the diversification a host country's international economicflows. An explicitly stated aim of diplomatic missions, and the trade promotion authorities that they often contain, is the diversification of a host country's trade and investment portfolios. Indeed, "[e]xport promotion agencies, foreign missions, and foreign service have been widely used to promote export activities of countries, with the goal of increasing export volumes, the number of firms that engage in export activities, the number of countries reached by domestic firms, and the diversification of those exporting activities in markets and goods" (9 SeguraCayuela and Vilarrubia, 2008, Emphasis Added). There is a great deal of anecdotal evidence to support this claim. For example, in a summary of a 2004 state-visit to Kenya by thenVietnamese Foreign Minster Dao Viet Trung, a Vietnamese newspaper noted that "[Kenya] relied on a few export commodities, namely, coffee, tea, sisal and pyrethrum but [Vietnam] has been implementing various policies aimed at promoting non-traditional exports over the past few years in order to minimize the vulnerability of the economy to any trade instability."9 Hence, foreign governments are actively using diplomacy to promote trade diversification in order to encourage trade stability. Regarding FDI, Thailand's ambassador to Laos recently emphasized his goal of encouraging more verticalized FDI flows (into Laos) in stating that the "Thai business council in Laos still wants quality businessmen and well-established companies to invest in Laos to help alleviate the country's problem of trade instability." 10 Thus, diplomatic

\footnotetext{
${ }^{9}$ Diplomatic Visit Boosts Ties with Congo, Kenya. 6 May 2004 Vietnam News Brief Service.

${ }^{10}$ Thailand: Laos optimistic about Thai investments. 12 September 2008 Thai News Service.
} 
missions are committed to the explicit promotion of trade and FDI diversification, often with the intended aim of reducing the volatility in commerce between their home and host countries. Given that diversification reduces trade volatility (Mansfield and Reinhardt, 2008, 629), one should therefore expect diplomatic-ties to do so as well.

\section{Negative Reinforcement Mechanisms}

In addition to the positive reinforcement mechanisms described above, alliances and diplomatic missions also exhibit a number of negative reinforcement mechanisms. These latter mechanisms differ from those described earlier in that they actually constrain governments and private actors from engaging in activities that increase trade volatility. We identify and discuss three complementary types of negative reinforcement mechanisms below: those that 'lock-in' states' existing commitments, those that prevent predatory state behaviors, and those that steer states away from engaging in, or exacerbating, international trade disputes. Regarding the first mechanism, Mansfield and Reinhardt (2008, 626-627) argue that—by committing states to a given level of trade openness in a manner that ties governments' hands against domestic pressure groups-international institutions reduce the probability of future protectionist barriers; and as a result, help states avoid the trade shocks that reversions to protectionism can cause. We argue directly below that alliances and diplomatic missions also help to 'lock-in' states' existing trade commitments in this manner, and therefore similarly increase the prospects of long-term trade stability among allied or diplomatically-tied countries.

Alliances and diplomatic corps specifically do so through two channels. First, these institutions help to establish and reinforce states' commitments to long-term trade openness. Indeed, a pair of countries that are linked by only a trade agreement would incur much lower costs from breaking that agreement—or temporarily violating its provisions-than would a pair of countries additionally bound by an alliance or set of diplomatic ties. Within the latter groups of countries, the costs of breaking-with or violating a trade agreement are compounded by domestic concerns that such actions will lead to a severing of alliance ties or diplomatic relations. For the many domestic actors that have vested interests in seeing political and security ties maintained between a pair of states irrespective of trade flows - such as military elite, diaspora networks, and epistemic communities—broken trade-promises may thus be perceived as a cred- 
ible threat to countries' broader relationships, and lobbied against by such groups. Moreover, as demonstrated above, alliances often include explicit trade-agreements in their provisions, which directly formalize and institutionalize state's trade relations in a manner that secures states' bilateral trade practices and commitments (Mansfield and Reinhardt, 2008, 627). Second, diplomatic missions also function within foreign countries as pro-trade interest groups, maneuvering at the behest of home-industries to lobby and counterbalance any protectionist sentiments within host countries. To the extent that alliance agreements include Defense Trade Cooperation Treaties, alliances may compel members' domestic military industries to behave in a similar manner. In these regards then, alliances and diplomatic ties shield governments from domestic, anti-trade pressure groups, and thereby help to 'lock-in' existing trade commitments.

A second negative reinforcement mechanism of interest arises from embassies and alliances' abilities to constrain government predation upon foreign industries and investments. Many governments, and especially those with weak institutional constraints, have the incentives and the capabilities to break existing agreements with firms in an effort to extort more rents (Stevens and Cooper, 2010, 588). Such behavior can increase a country's trade volatility through two channels. First, actual instances of predation can compel foreign firms to flee host countries, leading to boom-and-bust cycles of international investment and divestment. Second, a continued threat of predation also leads to lower or shallower ex-ante levels of foreign investment (Henisz, 2000; Stevens and Cooper, 2010), which ensures that any FDI that does occur in a country is easily moved and prone to capital flight under the very same boom-andbust cycles mentioned above. In these instances, it is therefore in the interests of both firms and governments to use institutions to constrain government actors from engaging in such predation. To this end, scholars have shown that alliances serve as one such institution (Mansfield and Bronson, 1997; Long, 2003). As Mansfield and Bronson argue, "[a]lliances can help regulate opportunism by foreign governments. Because open trade among allies promotes the security of members, governments have less incentive to behave opportunistically toward their allies' firms than toward firms of other states. Thus, private agents reduce the likelihood of opportunism - and enhance the expected profitability of investments—by investing in relationspecific assets to service allies' markets" (1997, 95). In doing so, alliances abate the harm that 
(potential) government opportunism does to FDI, and hence help alliance members stabilize and deepen their inter-member investment flows.

The foreign service also constrains host-government opportunism. Diplomats monitor host governments for predatory behaviors against home-country investments and punish such behaviors through three complimentary channels. Diplomatic missions help to disseminate and publicize instances of government predation through trade promotion authorities and published 'country-reports,' thereby increasing the costs of government predation by signaling to host governments that such actions can lead to public shaming and lower subsequent FDI. Second, through their political arrangements with host governments, diplomatic missions furnish direct lines of access to local politicians. Often, these ties create pressure points that can be used by foreign firms to directly lobby host-governments against engaging in opportunistic behavior. Where these efforts don't succeed, diplomatic missions also provide a direct, immediate, and discrete line of contact back to a home country's national government, which in the most-serious of cases can be used as an additional, high-level venue for lobbying host governments against predation. This channel thereby provides foreign firms facing predation with instant and confidential access to key actors and resources within the highest levels of their home-governments. One such example arose during a 1990s contract dispute between the U.S. company Enron and the Indian government over India's cancelation of Enron's Dabhol Power Project. Over the course of this dispute, which spanned both the Clinton and Bush II administrations, diplomatic channels were used by Enron to elicit state visits—or meetings with top Indian officials—on behalf of Enron by the U.S. Ambassador to India, Commerce Secretary, Treasury Secretary, Energy Secretary, Vice President, and Secretary of State. ${ }^{11}$ Hence, embassies provide international firms with both bottom-up and top-down protection against predation. By constraining predation in this manner, diplomatic missions curtail opportunism's trade-destabilizing effects.

The third negative reinforcement mechanism discussed here is that of dispute settlement provisions (DSPs). Within the arena of international trade, DSPs constrain governments' conflictive behaviors by providing a venue for cooperative dispute-settlement (Yarbrough and Yarbrough, 1997, 135). In this manner, DSPs function as 'pressure valves' and induce trade

11 "Fact Sheet: Background on Enron's Dabhol Power Project," Minority Staff Committee on Government Reform, U.S. House of Representatives, 22 February 2002.http://finance-mba.com/Dabhol_fact_sheet.pdf. 
stability by preventing countries from (i) escalating trade disputes to the level of a full-scale trade war or (ii) breaking from a trade agreement's provisions entirely (Rosendorff, 2005). DSPs thereby help countries address areas of specific trade dispute where they arise, rather than letting such issues 'spill-over' into other areas of economic and political exchange, which in turn helps to minimize the likelihood that a given dispute will lead to widespread trade volatility. Similarly, alliances often establish formal DSP rules, institutions, and mechanisms to peacefully resolve political disputes that arise between alliance-members. Indeed, as Long, Nordstrom and Baek note, alliances often "explicitly require that any disputes arising between the alliance members will be settled through peaceful mechanisms." (2007, 1107). Just as trade DSPs facilitate the cooperative settlement of trade disputes in a manner that prevents disagreements from spilling over into the broader political-interactions, the political DSPs found within alliances should reduce the likelihood that unsettled political or security disagreements spread into the arena of bilateral trade. Therefore, because international disputes arising within one area often spread to others, alliance-DSPs will help to prevent trade disputes and trade instability by ensuring that political-security disputes do not expand into economic areas.

While diplomatic missions do not establish DSPs of their own, they facilitate the use of existing trade DSPs through information provision and technical assistance. Trade promotion authorities supply extensive information to home governments about the details of host countries' markets and trade practices. When potential trade disputes do arise, such information provides aggrieved countries and industries with the incentives, evidence, and capacity to bring cases of trade dispute before international DSP bodies; reducing the likelihood that countries address such disputes through bilateral political channels. Because international DSPs solve information and coordination problems between disputing states (Yarbrough and Yarbrough, 1997), taking such an avenue for dispute settlement will help to ensure that states find a mutually agreeable dispute outcome rather than escalating a product-specific dispute to broader areas of trade and politics. Even when DSPs are not used, diplomatic missions constrain trade dispute escalation. When trade disputes arise, states are often limited in their abilities to publicly negotiate and make concessions to other governments due to domestic public opposition (Reinhardt, 1999; Fang, 2010). In these instances, embassies and diplomats allow for a secure 
negotiating channel between disputing states which in turn provides a venue for governments find an acceptable settlement absent any interference by domestic actors seeking to spoil a deal. Thus, diplomatic missions facilitate less costly dispute settlement by giving states better resources to both (i) engage in third party DSPs and (ii) find more efficient bilateral dispute settlements. Therefore, for countries with diplomatic relations, fewer trade disputes will escalate into the protectionist measures and trade wars that are known to exacerbate the volatility of bilateral trade flows between states.

\section{Hypotheses}

Having identified the specific mechanisms that enable alliances and diplomatic missions to reduce trade volatility, we can now clearly state two testable hypotheses:

- Hypothesis 1: Countries that are members to formal military alliances will have lower levels of trade volatility than those that do not hold such alliances.

- Hypothesis 2: Countries that have established foreign diplomatic missions in another country will have lower levels of trade volatility with that country than they will with other, non-diplomatically-linked trading partners.

\section{Analysis}

\section{Research Design}

The cross-sectional unit for our sample is directed dyad, and our sample encompasses all (directed) pairs of countries ( $i$ and $j$ ) in the world with available data for the years 1950-1999. Trade volatility is by definition the second moment (i.e. the variance or standard deviation) of trade flows, and ergo any measure of trade volatility must be calculated over (at least $t+1$ ) periods of time. We accordingly follow Rose $(2005,9)$ and measure trade volatility over two mutually exclusive and jointly exhaustive periods within our sample-frame: 1950-1974 and 1975-1999. Our primary analysis thereby employs a TSCS dataset with two 25-year temporalperiods $\left(t_{25}\right)$ and up-to 10,424 directed dyads per a 25 -year period. In the robustness section further below we also examine comparable TSCS datasets that utilize shorter (10 and 5 year) temporal aggregations of trade volatility. In keeping with Rose (2005), we then use a "gravity" 
model to estimate the effects of our covariates on a dyad's bilateral export volatility. Gravity specifications are commonly used in empirical models of bilateral trade-flows (Anderson, 1979; Bergstrand, 1985; Rose, 2004) and have gained prominence in recent studies of the effects of alliances and diplomatic missions on such trade flows (Mansfield and Bronson, 1997; Morrow, Siverson and Tabares, 1998; Long, 2003; Long and Leeds, 2006; Rose, 2007; Afman and Maurel, 2010). However, to our knowledge Rose (2005) presents the first and most comprehensive application of a gravity model to bilateral trade volatility, and we therefore directly build upon his modeling-approach here. ${ }^{12}$

The dependent variable for our gravity equation is Export Volatility $y_{i j} t_{25}$. In brief, this variable captures the volatility of country $i$ 's exports to country $j$ over the two 25 -year periods described above. To create Export Volatility ${ }_{i j}{ }_{25}$, we follow Rose (2005) in operationalizing trade volatility as the per-(25-year)-period coefficient of variation of country $i$ 's yearly exports to country $j$;

$$
\text { Export Volatility }_{i j t_{25}}=\frac{\sigma\left(\text { Export }_{i j t}\right)_{t_{25}}}{\mu\left(\text { Export }_{i j t}\right)_{t_{25}}}
$$

where $\sigma(\cdot)_{t_{25}}$ and $\mu(\cdot)_{t_{25}}$ are the standard deviation and mean operators computed over time $t_{25}$. Export $_{i j t}$ is measured as the natural logarithm of real bilateral exports from country $i$ to country $j$ in year $t .{ }^{13}$ Dropping the subscripts hereafter for notational convenience, higher values on this dependent variable (Export Volatility) thus denote less stable-i.e. more volatile-bilateral export flows from country $i$ to country $j$.

We create two separate independent variables to test Hypothesis 1 and 2. The first is Alliance, which captures the (per-period) average number of years that countries $i$ and $j$ have held formal alliance ties with each other. To create Alliance, we first used the Alliance Treaty Obligations and Provisions (ATOP) project (Leeds et al., 2002) to code a binary variable equal to one if a country $(i)$ has an alliance ${ }^{14}$ with country $j$ in year $t$, and zero otherwise. We then aggregate this yearly alliance indicator to per-period levels by taking its 25 -year period, directeddyad mean. To test Hypothesis 2 we construct the variable Diplomacyexp, which captures the

\footnotetext{
${ }^{12}$ And accordingly, we are very grateful to Andrew Rose for making available the data from Rose (2005); which we draw upon extensively in our analysis below.

${ }^{13}$ The trade data used to create Exports $s_{i j t}$ are taken from Rose (2005) and the International Monetary Fund's "Direction of Trade" (DoT) CD-ROM.

${ }^{14}$ I.e., a defense pact, neutrality pact, nonaggression pact, consultation pact, or offense pact.
} 
extent of diplomatic relations held by country $i$ in country $j$. To operationalize Diplomacyexp, we began by utilizing the Correlates of War's (COW) Diplomatic Exchange dataset (Bayer, 2006) to create a binary variable equal to 1 if country $i$ had established some level of diplomatic representation ${ }^{15}$ in country $j$ for year $t$, and zero otherwise. This yearly diplomacy measure is then aggregated to 25 -year periods by taking the average number of years within a given 25-year period that country $i$ had diplomatic representation in country $j$. We then create and include the reverse - that is, the level of diplomatic relations held by country $j$ in country $i$ (Diplomacy $_{\text {imp }}$ ) - in our models to further isolate and assess the hypothesized direct (tradestabilizing) effect of having a foreign mission on a trading partner's soil.

We next add a number of political controls to our gravity model in order to ensure that omitted variables are not biassing the effects of Diplomacyexp or Alliance on Export Volatility. Countries holding diplomatic relations or alliance ties are often found to be less likely to go to war with one another (Bremer, 1992; Long, Nordstrom and Baek, 2007), which in turn may affect trade flows and trade volatility (Anderton and Carter, 2001; Mansfield and Reinhardt, 2008). To control for the intervening effects of interstate conflict, we use data from the dyadic COW militarized interstate dispute (MID) dataset (Ghosn and Bennett, 2003) to code the average number of years within each 25-year period in which countries $i$ and $j$ were involved in a MID with one another $(M I D)$. Ideologically similar regimes—such as pairs of democracies or autocracies - are more likely both to hold alliances and to establish diplomatic relations with one another (Lai and Reiter, 2000; Neumayer, 2008). At the same time, pairs of democracies trade more more with one another than do other pairs of states (e.g., Mansfield, Milner and Rosendorff, 2000, 2002), while some have argued that shared democratic institutions underlie much of the bilateral trade promoting attributes of alliances (Morrow, Siverson and Tabares, 1998). We therefore control for the average number of years in each 25 -year period in which countries $i$ and $j$ are jointly democratic. To do so, we use Cheibub, Gandhi and Vreeland's (2010) binary democracy measure to code each country-year's level of democracy, and then construct a yearly Joint Democracy $y_{t}$ measure equal to one if countries $i$ and $j$ each were democracies in year $t$. Joint Democracy Dis $_{t}$ then aggregated to the 25 -year period level by taking the

\footnotetext{
${ }^{15}$ Such as a chargè d'affaires, minister, or ambassador.
} 
average number of years in which countries $i$ and $j$ were recorded as being a Joint Democracy.

To complete our gravity model specifications, we create and include in our models the traditional assemblage of gravity-model regressors. ${ }^{16}$ Following Rose (2005), we first calculate and add to our models per-period averages of yearly binary indicators (i.e., $1=$ true, $0=$ false) for exporter-country membership in the GATT/WTO $\left(G A T T_{\text {exp }}\right)$, importer-country membership in the GATT/WTO (GATT $\left.T_{\text {imp }}\right)$, dyadic generalized system of preference ties (GSP), joint free trade agreement membership (Regional FTA), and currency unions (Monetary union). We then add to our model the core set of gravity model controls, including the natural logarithm of the distance between $i$ and $j$ (Log Distance), the period-averaged natural logarithms of countries $i$ and $j$ 's real GDP $\left(G D P_{\text {exp }}\right.$ and $\left.G D P_{\text {imp }}\right)$, period-averaged natural logarithm of countries $i$ and $j$ 's populations ( Pop $_{\text {exp }}$ and $P o p_{i m p}$ ), the logged product of a country pair's area (Product area), dummy variables for common language and shared borders, and ordinal variables measuring whether none $(=0)$, one $(=1)$ or both $(=2)$ of the countries in a directed dyad are Landlocked or Island nations. Given our focus on export volatility, we additionally include the per-period standard deviations of the natural logarithm of each directed dyad-member's real GDP ( $S D G D P_{\text {exp }}$ and $\left.S D G D P_{\text {imp }}\right)$. Finally, we control for colonial ties by including (i) a binary variable equal to 1 if country pairs were colonies of the same colonizer during the post WWII-era (Common colonizer) and (ii) a binary variable equal to one if either member of a country pair was ever a colonizer of the other (Ever colony).

Rose (2005) conducts the most exhaustive analysis of bilateral export volatility to date, and we believe that a replication his main model specifications-in conjunction with the additional regressors described above-will provide for the most comprehensive test possible of our main hypotheses. Our primary analysis therefore closely follows Rose (2005) in estimating four main gravity model specifications. For the first specification, we estimate a pooled OLS model using all of the regressors described above, but including no fixed or random effects for cross-sectional units. We next estimate a model with two comprehensive sets of countryspecific intercepts - fixed importer and fixed exporter effects-in order to hold constant the effects of country-specific factors on our causal models. Next, we exchange these country-

\footnotetext{
${ }^{16}$ All gravity model controls listed here are taken from Rose (2005).
} 
specific intercepts for country-pair (directed-dyad) fixed effects, in order to account for any unobserved bilateral confounders. Finally, as a sensitivity test, we examine a fourth modelspecification that instead includes country-pair specific random effects. As with Rose (2005), we add period-fixed effects to all models, report clustered-robust standard errors, and place the most confidence in the two fixed effects specifications.

However, as evidenced both by the myriad of models examined in past studies of trade volatility (Rose, 2005; Mansfield and Reinhardt, 2008) and by the discussion above, there is clearly a lack of consensus on proper model specification within studies of international trade volatility. We therefore employ the use of Bayesian model averaging (BMA) as a final attempt to shore up any statistical discrepancies that have left scholars to conclude the matter unsettled. Among the battery of export-volatility models that have been estimated by Rose (2005) and others (Mansfield and Reinhardt, 2008), the common tendency has been to prefer models which include a variety of controls or fixed effects specifications in order to address the unobserved variation inherent within the international trade volatility debate. Though we believe, and existing literature suggests, that the fixed effects models are most likely the "true" models of this relationship, the alternative models specifications described above are still informative and should be included in this analysis.

Traditional tests of model "robustness" involve estimating a variety of alternative model specifications contingent on the guidance of expert opinion, existing literature, or prevailing statistical wisdom. Generally, if one's results are retained in the face of alternative tests and controls, a researcher concludes that the model is "robust" to alternative specifications. Though this approach may constitute the norm of political science research and address some of the uncertainty between model specifications, the practice itself vastly understates the degree of uncertainty about the effects of the variables of interest (Montgomery and Nyhan, 2010). By simply discriminating among a set possible models, estimating a few alternatives, but not allowing these different specifications to meaningfully contribute to the final set of reported results, we present an incomplete picture of trade volatility relationship.

BMA provides a solution to this statistical dilemma by directly addressing the uncertainty inherent in statistical modeling. In this manner BMA allows the researcher to evaluate the true 
robustness of one's results by conducting a battery of alternative specifications, and weighting these alternative models according to their posterior distributions (or probabilities) of how well the models predict the quantity of interest (Montgomery and Nyhan, 2010). In this sense, BMA "produces both parameter estimates and standard errors that more honestly reflect the observed variation of results across a range of possible models" (Bartels, 1997) by allowing each model to contribute to the final set of reported results. Hence, BMA is an estimation technique that allows researchers to incorporate both their prior beliefs and uncertainty in estimating their models. In some respects, it is thus a data driven process, relying on model parsimony and goodness of fit. In order to carry out this technique, a researcher must first decide how many models are necessary to estimate the quantity of interest. After identifying the relevant models and estimating their effects on the quantity of interest, scholars must select a Bayes factor which is a criterion used to evaluate the veracity of their model. The most intuitively used Bayes factor is the Bayesian Information Criteria (BIC), identified by (Raftery, 1995) as an approximate Bayes factor for model selection, that favors parsimonious models, penalizing models for as more parameters are added to the estimation (see Kass and Wasserman, 1995; Schwarz, 1978). In accordance with Bartels (1997), we use the formulas below for the calculating BIC, which consequently serves as an approximation of the Bayes factor for evaluating model performance:

$$
\begin{gathered}
-2 \ln (\theta \mid y)+2 k \ln (n)=B I C\left(M_{j}\right) \\
B I C\left(M_{j}\right) \approx-2 \ln (L)+2 k
\end{gathered}
$$

where $M_{j}$ is the set of models, where $j$ denotes the set of models, $n$ refers to the number of observations in each model, $L$ is the likelihood of one's model, and $k$ is equivalent to the number of parameters, and finally, $\theta$ is the likelihood we would have observed the model given $y$ the data. Overall the degree of uncertainty that is incorporated into the averaging stage depends on the prior beliefs of the researcher and theoretical expectations regarding the quantities of interest. After calculating the BIC, or approximate Bayes factor, for each model, researchers must decide on a Bayesian prior. Priors can take many different forms ranging from the well known uniform or multivariate distributions, to more unique ones like Cauchy and Wishart distribu- 
tions. In even more complex analyses, researchers can assign hyperpriors, such as Zellner's $g$, to their base priors reflecting increasing degrees of uncertainty in their analyses (Zellner, 1986; Montgomery and Nyhan, 2010). The following equation shows the notation of a prior.

$$
\operatorname{Pr}\left(M_{i}\right) \equiv \pi_{i}^{0}
$$

where $\pi_{i}^{0}$ is representative of a uniform prior for a specific model, which is the equivalence of the prior probability of observing model, notated as $\operatorname{pr}\left(M_{i}\right)$ with $i$ indexing a particular model in the set $j$. Typical critiques of this prior assignment technique are that it is heavily biased and subjective to the preferences of the researcher. We understand the uneasiness of this practice, but we argue that our approach is not to prefer one model to another. Rather, we seek to give each model a chance to influence this process. Because we believe that we have identified the correct set of models—but remain agnostic as to which model is true model—we assign a uniform prior allowing each model an equal prior probability of contributing information to our analyses, thus minimizing the subjectivity that is often criticized in the selection of priors. Once these priors are selected, we multiply them by our approximate Bayes factor (i.e. the BIC). After multiplication, these products are normalized by the sum of all Bayes factors corresponding to each model in order to return the posterior model probabilities displayed by:

$$
\pi_{i}=\frac{B_{i_{0}} \pi_{i}^{0}}{\Sigma_{j} B_{j_{0}} \pi_{j}^{0}}
$$

where $\pi_{i}$ is the posterior probability of observing a particular model $M_{i}$, that is equal to $B_{i_{0}}$, which is Bayes factor for one model subscripted by $i$ among the set of all our models $M_{j}$, multiplied by $\pi_{i}$, which is the uniform prior for each model, divided by the $\operatorname{sum} B_{j_{0}}$, which is the set of Bayes factors for all models, and $\pi_{j}^{0}$ is the set of uniform priors for all the models $j$. The returned posterior model probabilities are conditional on the performance of each model, which was determined by the product of the BIC and the prior in the previous equations. In the final stage, the averaging stage, the expected values of the coefficients approximate the sum of the product of the posterior model probabilities and their respective coefficients. In a similar approach, the variances are calculated by sum of the product of the posterior model proba- 
bilities and their respective coefficients plus the sum of the product of the squared deviations between the conditional and unconditional posterior means (Bartels, 1997). These equations are displayed below:

$$
E(\beta \mid X, y) \equiv \bar{b}=\Sigma_{j} \pi_{j} b_{j}
$$

where $E(\beta \mid X, y)$ is expected value of the coefficient estimate for the variables $X$ in a given model $y, \pi_{j}$ is the set of posterior probabilities for the models, and $\bar{b}$ is the vector of Bayesian model averaged coefficients.

$$
V(\beta \mid X, y)=\Sigma_{j} \pi_{j} V\left(b_{j}\right)+\Sigma_{j} \pi_{j}\left(b_{j}-\bar{b}\right)^{2}
$$

where $V(\beta \mid X, y)$ is the variance around the estimated model coefficients defined as $\beta, \pi_{j}$ is the set of posterior probability for the models, $b_{j}$ is a vector of coefficient values for set of models $M_{j}$, and $\bar{b}$ is the vector of BMA coefficient values defined above.

\section{Results}

The results from our main models appear in Table 1, and provide strong evidence for our expectations that alliance ties and diplomatic missions each independently work to reduce a country's bilateral export volatility. Beginning with our first model-specification in Table 1; that of the pooled OLS in column 1, one can note that our estimates for both Alliance and Diplomacy $_{\text {exp }}$ are negative and significant at the $p<.01$ level. Simply put, these results suggest that-over 25-year periods-having longer spells of alliance or diplomatic ties with a trading partner will significantly reduce the volatility of one's exports with that partner. The second and third models presented in Table 1, which report our exporter and importer fixed effects specification and our country-pair fixed effect specification respectively, confirm these preliminary findings. As before, the coefficient estimates for Alliance and Diplomacy exp are negative and significant at the $p<.01$ level. These results therefore reaffirm our hypotheses that alliance partners and countries with diplomatic ties enjoy less volatile trade. Similarly, the country-pair random effects model reported in the fourth column of Table 1 also estimates the coefficients on Alliance and Diplomacyexp to be negative and significant at the $p<.05$ level, further confirming our expectations of a negative relationship between international political 
ties and trade volatility.

However, for a truly comprehensive assessment of the robustness of these findings, one must assess the BMA coefficients and standard errors for these models. As mentioned previously, we believe that we have identified a plausible set of trade volatility models for our hypotheses testing, as our four main models are motivated by and directly build upon the existing empirical research on this topic. Yet unlike past studies we remain agnostic as to which model best encapsulates the true underlying relationship between our variables and trade volatility. Rather, we argue that each model contributes valuable information to this debate. The final set of reported results in Table 1 reflects this theoretical belief by reporting uniform-priors BMA coefficient estimates and standard errors for the aforementioned four models. These results demonstrate that, even after accounting for the disagreement across model selection and the variability within each model, our findings remain robust to the alternative specifications espoused in the literature. Hence, the results of the Bayesian model averaging support our hypotheses and sustain our initial conclusions that alliance partners and countries that share diplomatic ties incur less trade volatility than those who do not share such privileges. As indicated in column 5 , the signs on both the coefficients for Alliance and Diplomacy $y_{\exp }$ are negative and significant $(p<.01)$. Furthermore, due to the process of Bayesian model averaging, their magnitudes are attenuated and standard errors slightly inflated which is consistent with our statistical expectations.

Finally, note that many of our gravity model variables' coefficient estimates remain statistically significant in their expected directions within the reported BMA results. Among them, the signs on $G S P, G D P_{\text {exp }}, G D P_{\text {imp }}$, and Com. colonizer are all negative and significant, which is consistent with theoretical expectations. Indeed, pairs of countries who share preferential duty free trade relationships, are wealthier, and have similar colonial histories all should experience more diverse and integrated trade ties, and hence less trade volatility, than those countries which do not reflect these characteristics. In addition, the sign on Log distance is positive and statistically significant in our BMA results. This indicates that trade volatility is correlated with increasing physical distance between countries, again confirming expectations. At the same time, the coefficient estimates for several other key controls, such as GATT $T_{\text {exp }}$, Regional FTA, and Joint Demomcracy — although in their expected directions — are not statistically distinguishable 
from zero in our final Bayesian model averaged estimates, suggesting that these variables' effects are not robust across our four main models. Note that this is not necessarily evidence of these control variables' non-significance, as it may very well be the case that a different or more nuanced BMA weighting scheme-favoring some of our four main models over otherswould yield more highly significant BMA coefficients for these covariates. However, given the theoretical focus of this paper, and the lack of prior justification for definitively weighting some subset of our four models over others, we refrain from such an exercise in the paper at hand.

\section{[Insert Table 1 about here]}

To gain a better substantive sense of these results, we next graph the mean marginal effects of a per-period change from 0-to-1 in Alliance, Diplomacyexp, or Joint Diplomacy (i.e. Diplomacy $_{\text {exp }}+$ Diplomacy $_{\text {imp }}$ ) on Export Volatility, along with their 95\% confidence intervals. These marginal effects appear in Figure 1 and indicate that the effect of a dyad becoming allied or gaining diplomatic relations is indeed sizable. In particular, we can first note that holding alliance ties with a trading partner is expected to reduce a country's export volatility by a Baysian model averaged effect of approximately $13 \%$. Second, observe that the effect of establishing a diplomatic mission on a trading partner's soil for a given 25 -year period has a comparable effect on a country's trade stability, with the BMA effects reported in Figure 1 suggesting that such diplomatic ties will reduce a country's export volatility by roughly $16 \%$. This effect is even more pronounced when dual diplomatic ties - that is, the presence of diplomatic missions on both trading partner's soils—are taken into account. Indeed, as Figure 1 indicates, the effect of both trading partner's having diplomatic missions on the others' soil-relative to neither having such missions-is predicted to reduce an exporter's level of export volatility by approximately $26 \%$ during a 25 -year period. Thus, our main models in Table 1 suggest that alliances and diplomatic ties each have a significant—and substantively sizable—negative effect on a dyad's long term trade volatility.

\section{[Insert Figures 1 and 2 about here]}

Figure 2 next compares the magnitudes of these main, BMA substantive effects to those of several of key control variables that have been suggested by previous literature to have ef- 
fects on trade volatility. Specifically, we include for comparison the BMA-derived marginal effects (and 95\% CIs thereof) from five key control variables; joint GATT/WTO membership $\left(G A T T_{\text {exp }}+G A T T_{\text {imp }}\right)$, Regional FTA, joint GSP and Common colonizer, and examine the effect of an increase from 0-to-1 on each variable. As we can first see in Figure 2, the estimated negative effects of Alliance, Diplomacyexp, Joint Diplomacy are far larger in magnitude than that of joint GATT/WTO membership, are comparable in size to Regional FTA, and outperform both controls in statistical significance. On the other hand, GSP and Common colonizer each have a significantly larger effect on trade volatility than do our key independent variables of Alliance, Diplomacyexp. This is unsurprising, given the sheer volume of bilateral goods that generalized systems of preferences generally encompass; and the shared political-economic institutions, culture, and trade-access that former colonies often exhibit (e.g. Commonwealth of Nations). Thus, the marginal effects presented here suggest that our main hypothesized variables; Alliance and Diplomacyexp have substantive effects that are sizable, but not atypical.

\section{Robustness Models}

To further evaluate the sensitivity of the above findings, we next assess the robustness of our results under seven alternative model specifications. In each of our seven robustness tests, we estimate the four main specifications presented above (i.e. pooled OLS, importer and exporter FE, country pair FE, and country pair RE) and BMA the results from each specification. For each test, Table 2 then reports the corresponding coefficient estimates and standard errors for only our main variables of interest; Alliance and Diplomacyexp (we omit the control variables to save space). The first robustness model in Table 2 adds three additional control variables to our main specifications; Alliance Volatility, Diplomacyexp Volatility, and,

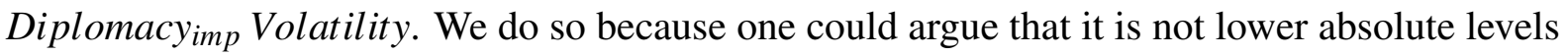
of alliance or diplomatic ties that are leading to findings of higher volatility, per say. Rather, pairs of countries involved in higher levels of contentious diplomatic behavior (i.e. diplomatic disputes, rivalries, etc.) may both (i) have higher trade volatility, and (ii) have lower per-period averages of diplomatic and alliance ties. As one can see in Table 2, controlling for these volatility measures does not affect the robustness of our results. Similarly, countries encountering more regime transitions could be claimed to have both less stable trade and fewer diplomatic 
or alliance ties. ${ }^{17}$ Accordingly, we next hold constant the (natural log of the per-period sum of) exporter and importer regime transitions, and find in our second set of robustness models that doing so has no effect on our primary coefficient estimates.

\section{[Insert Table 2 about here]}

Recent studies report that country level (i.e. monadic) measures of both democracy and militarized conflict (among both exporters and importers) affect short term export volatility (Mansfield and Reinhardt, 2008). Robustness models three and four in Table 2 therefore include per-period averages of monadic conflict and monadic democracy levels for both exporters and importers in order to demonstrate that including these controls does not affect the robustness of our findings. ${ }^{18}$ In line with (Rose, 2005), we next drop any outlying observations for which the residual was larger than three standard deviations from the mean. Table 2 demonstrates that dropping these outliers does not affect our results. Finally, tests six and seven evaluate our dependent and independent variables over two alternative temporal levels of aggregation; 10 and 5 year periods, which allows for more variation in our variables of interest (Rose, 2005, 15-16). Note however, that this added variation comes at the expense of reliability, as our per period measures are now being derived from fewer underlying observations (Rose, 2005, 15-16). As can be seen in the final two robustness models, Diplomacyexp remains significant under all alternative temporal aggregations. However, Alliance does not fair as well, at times maintaining significance but — as indicated by the BMA results—-failing to maintain significance at least at the $p<.05$ level across all models. These null findings may suggest that the effect of alliances on trade-stability may be dependent upon these agreements' abilities to lock-in or induce subsequent long-term trade commitments, and that accordingly alliances themselves may do little to safeguard trade flows against short-term trade decisions and shocks.

\footnotetext{
${ }^{17}$ See e.g., Siverson and Starr (1994) for findings relating regime changes to states' decisions to restructure alliances and Gitelson (1974) for arguments suggesting that regime changes can compel states to severe existing diplomatic relations.

${ }^{18}$ For each dyad member, monadic conflict was set equal to one for years in which a country experienced either interstate or intrastate war according to the UCDP/PRIO Armed Conflict Dataset (Gleditsch et al., 2002), and zero otherwise; and per-period averages of these values were then used to create Monadic conflict exp $_{\text {and }}$ Monadic conflict imp. Democracy $_{\text {exp }}$ and Democracy Dimp $_{\text {p }}$ are per-period averages of the number of years in which each country was coded as a democracy according to Cheibub, Gandhi and Vreeland (2010).
} 


\section{Conclusion}

This paper argues and finds that international political institutions can reduce trade volatility. Specifically, we theorize that international political ties—such as alliances or diplomatic missions-will help to steady trade flows by (i) stabilizing international investor-confidence and expectations (ii) restricting acts of predation and protectionism by participating-governments and (iii) diversifying, reinforcing, and deepening trade-ties and FDI-flows among member states. In support of these expectations, we find that the establishment of diplomatic relations or alliances with a trading partner significantly reduces a country's bilateral export volatility. Indeed, countries holding alliance ties with one another over a 25 -year period were estimated in our models to have $15 \%$ less volatility in their exports than those that do not, whereas pairs of countries holding joint diplomatic ties over a comparable period of time were estimated to have $25 \%$ less export volatility than comparable pairs of states with no diplomatic relations. These effects are sizable, and are comparable to-or larger than — the estimated effects of many other variables that are often argued or found to affect trade volatility, such as FTA and GATT/WTO membership, customs unions, or common colonial ties. Our findings are also remarkably robust, and remain consistent across multiple operationalizations of our key variables, over 32 model specifications, and after accounting for over 30 potentially confounding covariates.

Given the many threats posed by trade volatility (Rodrik, 1998, 1999; Aizenman, 2003; Scheve and Slaughter, 2004; Mansfield and Reinhardt, 2008), our findings have a number of important theoretical and policy implications. As a whole, the trade stabilizing effects of alliances and diplomatic missions imply that one of the greatest challenges faced by globalizing states today — that of trade instability or 'trade shocks' — can be mitigated by the careful establishment and maintenance of international political ties. Ergo, alliances and diplomatic missions are not simply artifacts of a bygone (pre-WWII) era, but rather, continue to function as critical components to the international political economy of nation states. In this manner, this paper furthers our understanding of the role of international political institutions within the political economy of globalization. In addition, our results contribute to theories of alliances and diplomatic missions' effects on trade, which together represent a burgeoning area of research (Long, 2003; Long and Leeds, 2006; Rose, 2007; Gil, Llorca and Serrano, 2008; 
Segura-Cayuela and Vilarrubia, 2008; Afman and Maurel, 2010). In doing so, this paper also heeds recent calls for international relations scholars to focus more on (i) the study of diplomacy in our research (Sharp, 1999) and (ii) the role of commercial and business interests in our analyses of diplomacy (Lee and Hudson, 2004). Lastly, while the study of trade volatility, and its political determinants, is central to our understanding of the modern international political economy, we have yet to explain the bulk of the variation found within trade volatility (Rose, 2005, 12). By building upon and synthesizing the existing research in this area (Rodrik, 1998; Rose, 2005; Mansfield and Reinhardt, 2008), it is hoped that the current study brings us one step closer towards this goal; a better understanding of trade volatility and its political roots.

Our results also illuminate several fruitful avenues of future research. One way in which our findings could be directly improved upon would be through a better explication of the specific causal mechanisms that underlie the relationship between international political institutions and trade stability. Identifying which of the many causal mechanisms identified above have the most sizable effects on trade stability would help to do so. Here, a disaggregation of alliance features in a manner similar to that preformed in recent studies of alliances and trade flows (Long, 2003; Long and Leeds, 2006) would be an excellent starting point. Another interesting vein of future analysis would be an assessment of the stabilizing effects of alliances or diplomatic ties on other types of international economic exchange, such as those associated with financial markets, foreign aid, or military assistance. Volatility in these economic flows has-like trade volatility—been shown to do significant harm to countries (Bulîr and Hamann, 2008; Nielsen et al., 2011), and hence an exploration of whether the virtuous trade stabilizing features (identified for diplomatic and alliance ties above) extend to these alternative economic flows would be extremely beneficial to both theory and policy. Finally, while the trade-stabilizing effects of domestic democratic institutions are well established (Rodrik, 1998; Adserà and Boix, 2002), we lack a comprehensive understanding of how other domestic political factors affect trade volatility. Regime transitions, coups, civil wars, authoritarian regime types, and political corruption, to name a few examples, have to our knowledge remained understudied in this regard, and hence we believe that further research on these factors' potential effects on trade volatility would make for an important contribution. 


\section{References}

Adserà, Alicia and Carles Boix. 2002. "Trade, Democracy, and the Size of the Public Sector: The Political Underpinnings of Openness." International Organization 56.

Afman, Emiel and Mathilde Maurel. 2010. Diplomatic Relations and Trade Reorientation in Transition Countries. In The Gravity Model in International Trade: Advances and Applications, ed. Peter A. G. van Bergeijk and Steven Brakman. Cambridge: Cambridge University Press.

Aizenman, Joshua. 2003. "Volatility, Employment, and the Patterns of FDI in Emerging Markets." Journal of Development Economics 72.

Anderson, James E. 1979. “A Theoretical Foundation for the Gravity Equation.” American Economic Review 69.

Anderton, Charles H. and John R. Carter. 2001. “The Impact of War on Trade: An Interrupted Times-Series Study.” Journal of Peace Research 38.

Bartels, Larry M. 1997. "Specification Uncertainity and Model Averaging.” American Journal of Political Science 41:641-674.

Bayer, Reşat. 2006. "Diplomatic Exchange Data set, v2006.1.” http://correlatesofwar.org.

Bergstrand, Jeffrey H. 1985. "The Gravity Equation in International Trade: Some Microfoundations and Empirical Evidence.” Review of Economics and Statistics 67.

Bernhard, William and David Leblang. 2006. Democratic Processes and Financial Markets: Pricing Politics. New York: Cambridge University Press.

Blattman, Christopher, Jason Hwang and Jeffery G. Williamson. 2007. "Winners and Losers in the Commodity Lottery: The Impact of Terms of Trade Growth and Volatility in the Periphery 1870Û1939.” Journal of Development Economics 82.

Bremer, Stuart A. 1992. "Dangerous Dyads : Conditions Affecting the Likelihood of Interstate War, 1816-1965." Journal of Conflict Resolution 36. 
Buliřr, Aleš and Javier Hamann. 2008. "Volatility of Development Aid: From the Frying Pan into the Fire?" World Development 36.

Cheibub, Jose Antonio, Jennifer Gandhi and James Raymond Vreeland. 2010. "Democracy and Dictatorship Revisited." Public Choice 143(1-2):67-101.

Cohen, Raymond. 1999. Reflections on the New Global Diplomacy: Statecraft 2500 BC to 2000 AD. In Innovation in Diplomatic Practice (Studies in Diplomacy), ed. Jan Melisson. New York, New York: Palgrave.

Duffield, John S. 1992. "International Regimes and Alliance Behavior: Explaining NATO Conventional Force Levels.” International Studies Quarterly 46(4):819-855.

Fang, Songying. 2010. “The Strategic Use of International Institutions in Dispute Settlement.” Quarterly Journal of Political Science 5:107-131.

Fiala, Nathan. 2009. "When More is Too Much: The Effect of Rainfall Shocks on Economic Growth and Civil Conflict." Working Paper.

Ghosn, Faten and Scott Bennett. 2003. "Codebook for the Dyadic Militarized Interstate Incident Data, Version 3.10.” http://correlatesofwar.org.

Gil, Salvador, Rafael Llorca and José A. Martínez Serrano. 2008. "Measuring the Impact of Regional Export Promotion: The Spanish Case." Papers in Regional Science 87(1):139-146.

Gitelson, Susan Aurelia. 1974. "Why do Small States Break Diplomatic Relations with Outside Powers?: Lessons from the African Experience.” International Studies Quarterly 18(4):451484.

Gleditsch, Nils Petter, Peter Wallensteen, Mikael Eriksson, Margareta Sollenberg and Havard Strand. 2002. “Armed Conflict 1946-2001: A New Dataset.” Journal of Peace Research 39(5):615-637.

Grimes, Arthur. 2006. “A Smooth Ride: Terms of Trade, Volatility and GDP growth.” Journal of Asian Economics 17(4):583-600. 
Haftendorn, Helga. 2011. "NATO and the Arctic: is the Atlantic Alliance a Cold War Relic in a Peaceful Region now Faced with Non-Military Challenges?” European Security 20(3):337361.

Heine, Jorge. 2006. "On the Manner of Practising the New Diplomacy." The Center for International Governance Innovation Working Paper No. 11.

Henisz, W.J. 2000. “The Institutional Environment for Economic Growth.” Economics \& Politics $12(1): 1-31$.

Hidalgo, F. Daniel, Suresh Naidu, Simeon Nichter and Neal Richardson. 2010. "Economic Determinants of Land Invasions.” The Review of Economics and Statistics 92(3):505-523.

Kaminsky, Graciela and Carment Reinhart. 1999. "The Twin Crises: Causes of Banking and Balance of Payments Problems.” American Economic Review 89(3):473-500.

Kass, Robert E. and Larry Wasserman. 1995. "A Reference Bayesian Test for Nested Hypotheses and Its Relationship to the Schwarz Criterion." Journal of American Statistical Association (431):928-934.

Kim, So Young. 2007. “Openness, External Risk, and Volatility: Implications for the Compensation Hypothesis.” International Organization 62(3):477-505.

Kose, M. Ayhan, Eswar S. Prasad and Marco E. Terrones. 2003. "How Does Globalization Affect the Synchronization of Business Cycles?" The American Economic Review 93(2):5762.

Lai, Brian and Dan Reiter. 2000. "Democracy, Political Similarity, and International Alliances, 1816-1992." Journal of Conflict Resolution 44(2).

Lee, Donna and David Hudson. 2004. "The Old and New Significance of Political Economy in Diplomacy.” Review of International Studies 30:343-360.

Leeds, Brett Ashley, Jeffrey M. Ritter, Sara McLaughlin Mitchell and Andrew G. Long. 2002. “Alliance Treaty Obligations and Provisions.” International Interactions 28:237-260. 
Long, Andrew G. 2003. "Defense Pacts and International Trade.” Journal of Peace Research 40(5).

Long, Andrew G. and Brett Ashley Leeds. 2006. "Trading for Security: Military Alliances and Economic Agreements." Journal of Peace Research 43(4).

Long, Andrew G., Timothy Nordstrom and Kyeonghi Baek. 2007. "Allying for Peace: Treaty Obligations and Conflict between Allies.” Journal of Politics 69(4).

Mansfield, Edward D. and Eric Reinhardt. 2008. "International Institutions and the Volatility of International Trade.” International Organization 62(4).

Mansfield, Edward D., Helen V. Milner and B. Peter Rosendorff. 2000. "Free to Trade: Democracies, Autocracies, and International Trade.” The American Political Science Review 94(2).

Mansfield, Edward D., Helen V. Milner and B. Peter Rosendorff. 2002. "Why Democracies Cooperate More: Electoral Control and International Trade Agreements.” International Organization 56(3).

Mansfield, Edward D. and Rachel Bronson. 1997. "Alliances, Preferential Trading Arrangements, and International Trade.” The American Political Science Review 91(1).

Miguel, Edward, Shanker Satyanath and Ernest Sergenti. 2008. "Economic Shocks and Civil Conflict: An Instrumental Variables Approach.” Journal of Political Economy 112(4).

Montgomery, Jacob and Brendan Nyhan. 2010. "Bayesian Model Averaging: Theoretical Developments and Practical Applications.” Political Analysis 18(2):245-270.

Morrow, James D., Randolph M. Siverson and Tressa E. Tabares. 1998. “The Political Determinants of International Trade: The Major Powers, 1907-90.” The American Political Science Review 92(3).

Neumayer, Eric. 2008. "Distance, Power and Ideology: Diplomatic Representation in a World of Nation-States." Area 40(2). 
Nielsen, Richard A., Michael G. Findley, Zachary S. Davis, Tara Candland and Daniel L. Nielson. 2011. "Foreign Aid Shocks as a Cause of Violent Armed Conflict." American Journal of Political Science 55(2).

Quinn, Dennis P. and John T. Woolley. 2001. "Democracy and National Economic Performance: The Preference for Stability." American Journal of Political Science 45(3).

Raftery, Adrian. 1995. Bayesian Model Selection in Social Research. In Sociological Methodology, ed. Peter V. Marsden. Cambridge, MA: Blackwells.

Razin, Assaf, Efraim Sadka and Tarek Coury. 2003. “Trade Openness, Investment Instability and Terms-of-Trade Volatility." Journal of International Economics 61(2):285-306.

Reinhardt, Eric. 1999. “Aggressive Multilateralism: The Determinants of GATT/WTO Dispute Initiation, 1948-1998.” Working Paper.

Rodrik, Dani. 1998. “Why Do More Open Economies Have Bigger Governments.” Journal of Political Economy 106(5):997-1032.

Rodrik, Dani. 1999. "Where Did All the Growth Go? External Shocks, Social Conflict, and Growth Collapses.” Journal of Economic Growth 4(4):385-412.

Rose, Andrew K. 2004. "Do We Really Know that the WTO Increases Trade?" American Economic Review 94(1).

Rose, Andrew K. 2005. “Does the WTO Make Trade More Stable?" Open Economies Review 16(1).

Rose, Andrew K. 2007. “The Foreign Service and Foreign Trade: Embassies as Export Promotion." The World Economy 30(1).

Rosendorff, B. Peter. 2005. "Stability and Rigidity: Politics and Design of the WTO's Dispute Settlement Procedure.” American Political Science Review 99(3):389-400.

Scheve, Kenneth and Matthew J. Slaughter. 2004. "Economic Insecurity and the Globalization of Production.” American Journal of Political Science 48(4). 
Schwarz, Gideon. 1978. "Estimating the Dimension of a Model.” Annals of Statistics 6(2).

Segura-Cayuela, Rubén and Josep M. Vilarrubia. 2008. “The Effect of Foreign Service on Trade Volumes and Trade Partners.” Documentos de Trabajo No. 0808, Banco De España.

Sharp, Paul. 1999. "For Diplomacy: Representation and the Study of International Relations." International Studies Review 1(1).

Singer, J. David and Melvin Small. 1966. "The Composition and Status Ordering of the International System: 1815-1940.” World Politics 18(2).

Singer, J. David and Melvin Small. 1973. “The Diplomatic Importance of States, 1816-1970: An Extension and Refinement of the Indicator." World Politics 25(4).

Siverson, Randolph M. and Harvey Starr. 1994. "Regime Change and the Restructuring of Alliances." American Journal of Political Science 38(1).

Stevens, Charles E. and Joseph T. Cooper. 2010. “A Behavioral Theory of Governments' Ability to Make Credible Commitments to Firms: The Case of the East Asian Paradox." Asia Pacific Journal of Management 27(4).

Talbott, Strobe. 1997. “Globalization and Diplomacy: A Practitioner's Perspective.” Foreign Policy (108).

Yarbrough, Beth V. and Robert M. Yarbrough. 1997. Dispute Settlement in International Trade: Regionalism and Procedural Coordination. In The Political Economy of Regionalism, ed. Edward Mansfield and Helen V. Milner. New York City, New York: Columbia University Press.

Zellner, Arnold. 1986. On Assessing Prior Distributions and Bayesian Regression Analysis with G-prior Distributions. In Bayesian inference and decision techniques: Essays in honor of Burno de Finetti, ed. Prem K. Goel and Arnold Zellner. North Holland, Netherlands: Elsevier. 
Figure 1: Effect of Independent Variables on Trade Volatility

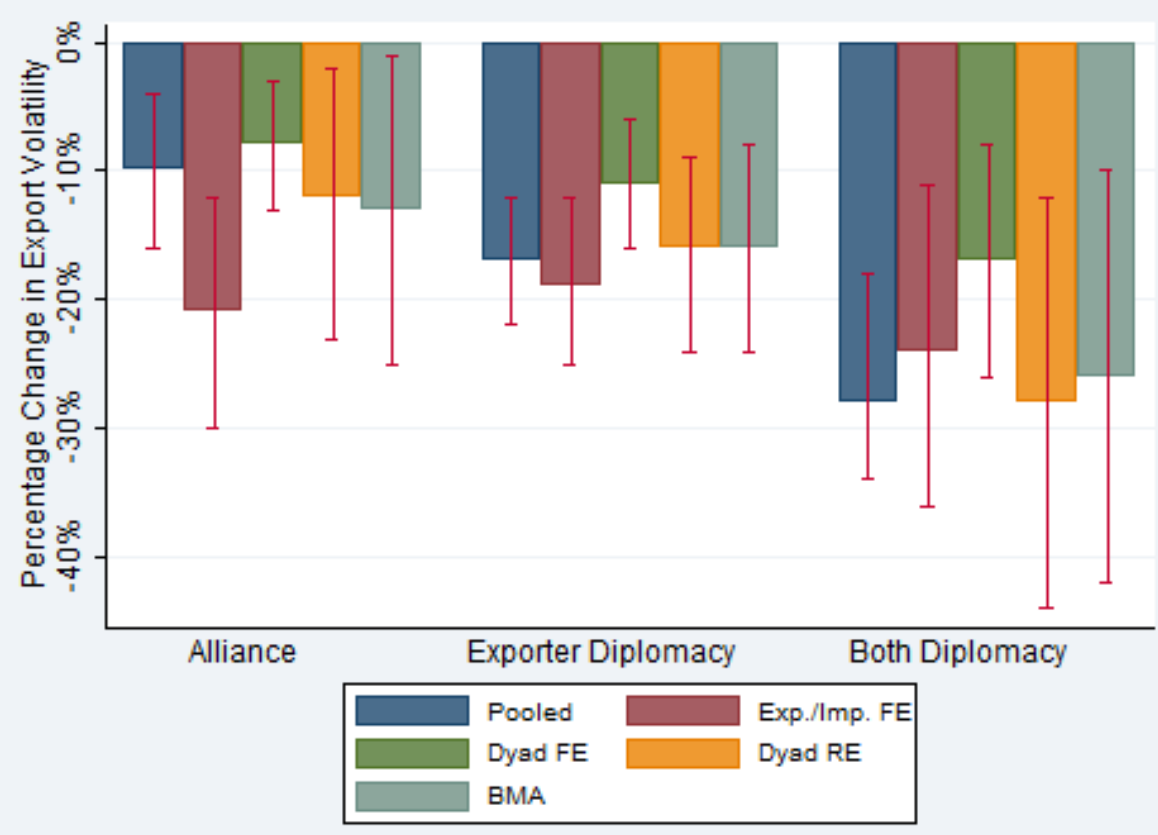

Figure 2: Comparisons of Variables' Effects on Trade Volatility

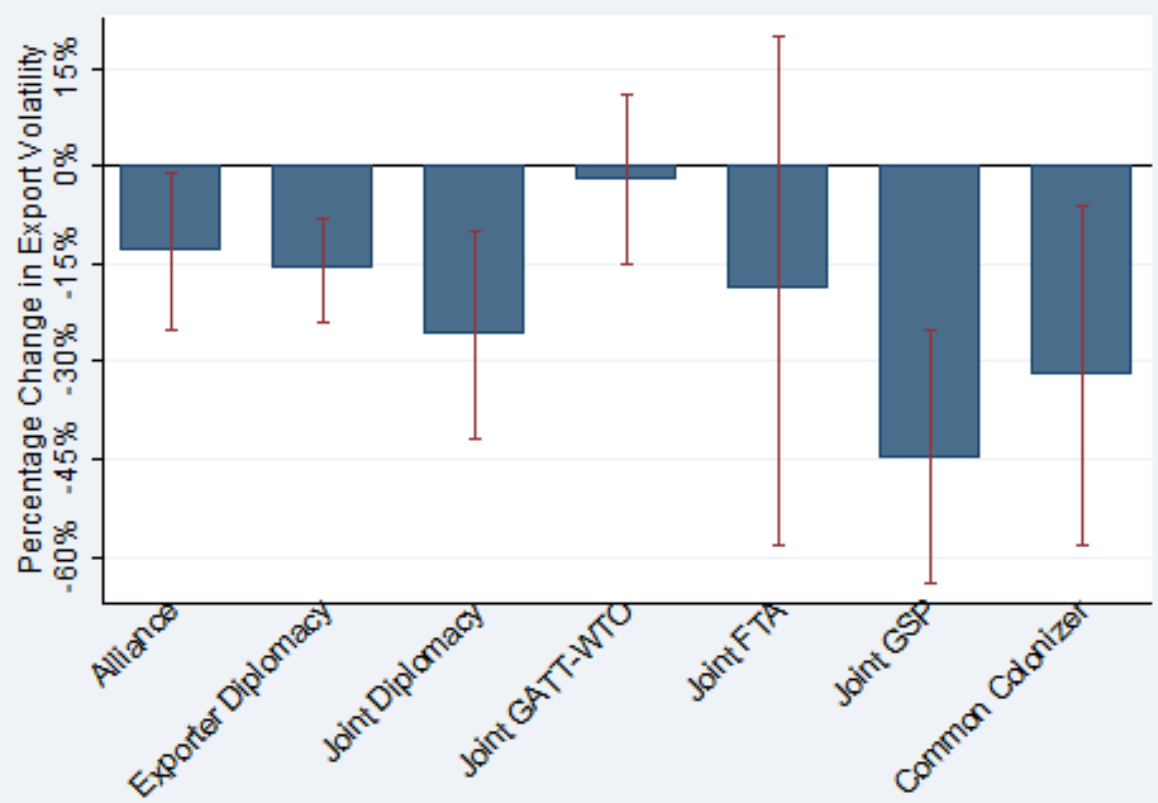

Figures \& Tables 
Table 1: International Political Determinants of Export Volatility, 1950-1999

\begin{tabular}{|c|c|c|c|c|c|}
\hline & Pooled & $\begin{array}{l}\text { Fixed Exp., } \\
\text { Imp. effects }\end{array}$ & $\begin{array}{l}\text { Dyad } \\
\text { FE's }\end{array}$ & $\begin{array}{l}\text { Dyad } \\
\text { RE's }\end{array}$ & $\overline{\text { BMA }}$ \\
\hline Alliance & $\begin{array}{c}.018 * * \\
(.006)\end{array}$ & $\begin{array}{c}.038 * * \\
(.008)\end{array}$ & $\begin{array}{c}-015 * * \\
(.005)\end{array}$ & $\begin{array}{l}.022 * \\
(.010)\end{array}$ & $\begin{array}{c}.023 * * \\
(.011)\end{array}$ \\
\hline Diplomacy $_{\exp }$ & $\begin{array}{c}-.030 * * \\
(.005)\end{array}$ & $\begin{array}{c}-.034 * * \\
(.006)\end{array}$ & $\begin{array}{c}-.020 * * \\
(.004)\end{array}$ & $\begin{array}{c}-.030 * * \\
(.007)\end{array}$ & $\begin{array}{c}-.029 * * \\
(.007)\end{array}$ \\
\hline Diplomacy $_{\text {imp }}$ & $\begin{array}{c}-.020 * * \\
(.005)\end{array}$ & $\begin{array}{l}-.009 \\
(.006)\end{array}$ & $\begin{array}{c}-.012 * * \\
(.004)\end{array}$ & $\begin{array}{c}-.021 * * \\
(.007)\end{array}$ & $\begin{array}{c}-.018 * * \\
(.008)\end{array}$ \\
\hline$M I D$ & $\begin{array}{l}.065 \\
(.036)\end{array}$ & $\begin{array}{l}.101 * \\
(.042)\end{array}$ & $\begin{array}{c}.047 \\
(.036)\end{array}$ & $\begin{array}{l}.056 \\
(.079)\end{array}$ & $\begin{array}{c}.064 \\
(.066)\end{array}$ \\
\hline Joint Dem & $\begin{array}{l}-.020^{*} \\
(.008)\end{array}$ & $\begin{array}{l}.028 * \\
(.013)\end{array}$ & $\begin{array}{l}-.007 \\
(.005)\end{array}$ & $\begin{array}{l}-.020^{*} \\
(.009)\end{array}$ & $\begin{array}{l}-.011 \\
(.002)\end{array}$ \\
\hline$G A T T_{\exp }$ & $\begin{array}{c}-.026^{* *} \\
(.006)\end{array}$ & $\begin{array}{l}.039 * \\
(.017)\end{array}$ & $\begin{array}{c}-.030 * * \\
(.005)\end{array}$ & $\begin{array}{c}-.027 * * \\
(.006)\end{array}$ & $\begin{array}{l}-.017 \\
(.026)\end{array}$ \\
\hline$G A T T_{i m p}$ & $\begin{array}{l}.017 * * \\
(.006)\end{array}$ & $\begin{array}{l}.035^{*} \\
(.016)\end{array}$ & $\begin{array}{l}-.001 \\
(.006)\end{array}$ & $\begin{array}{l}.008 \\
(.006)\end{array}$ & $\begin{array}{c}.013 \\
(.014)\end{array}$ \\
\hline$G S P$ & $\begin{array}{c}-.101 * * \\
(.005)\end{array}$ & $\begin{array}{c}-.085^{* *} \\
(.006)\end{array}$ & $\begin{array}{c}-.040 * * \\
(.005)\end{array}$ & $\begin{array}{c}-.082 * * \\
(.008)\end{array}$ & $\begin{array}{c}-.081 * * \\
(.018)\end{array}$ \\
\hline Regional FTA & $\begin{array}{l}-.008 \\
(.015)\end{array}$ & $\begin{array}{c}.009 \\
(.018)\end{array}$ & $\begin{array}{c}-.065^{* *} \\
(.010)\end{array}$ & $\begin{array}{l}-.049 \\
(.030)\end{array}$ & $\begin{array}{l}-.035 \\
(.036)\end{array}$ \\
\hline Monetary union & $\begin{array}{l}-.021 \\
(.013)\end{array}$ & $\begin{array}{l}-.031 \\
(.018)\end{array}$ & $\begin{array}{c}.010 \\
(.014)\end{array}$ & $\begin{array}{l}-.008 \\
(.028)\end{array}$ & $\begin{array}{l}-.012 \\
(.026)\end{array}$ \\
\hline$G D P_{\exp }$ & $\begin{array}{c}-.043^{* *} \\
(.003)\end{array}$ & $\begin{array}{c}-.092^{* *} \\
(.010)\end{array}$ & $\begin{array}{c}-.042 * * \\
(.004)\end{array}$ & $\begin{array}{c}-.052 * * \\
(.003)\end{array}$ & $\begin{array}{c}-.056 * * \\
(.017)\end{array}$ \\
\hline$G D P_{i m p}$ & $\begin{array}{c}-.033^{* *} \\
(.003)\end{array}$ & $\begin{array}{c}-.097 * * \\
(.015)\end{array}$ & $\begin{array}{c}-.030 * * \\
(.003)\end{array}$ & $\begin{array}{c}-.040 * * \\
(.003)\end{array}$ & $\begin{array}{c}-.046 * * \\
(.023)\end{array}$ \\
\hline$S D G D P_{\exp }$ & $\begin{array}{c}.011 \\
(.020)\end{array}$ & $\begin{array}{l}.040 * \\
(.016)\end{array}$ & $\begin{array}{l}.033^{*} \\
(.014)\end{array}$ & $\begin{array}{l}.015 \\
(.015)\end{array}$ & $\begin{array}{l}.020 \\
(.019)\end{array}$ \\
\hline$S D G D P_{i m p}$ & $\begin{array}{c}.001 \\
(.017)\end{array}$ & $\begin{array}{l}.071 * * \\
(.019)\end{array}$ & $\begin{array}{c}.009 \\
(.013)\end{array}$ & $\begin{array}{l}-.003 \\
(.015)\end{array}$ & $\begin{array}{c}.011 \\
(.031)\end{array}$ \\
\hline Pop $_{\text {exp }}$ & $\begin{array}{c}-.032 * * \\
(.002)\end{array}$ & $\begin{array}{l}.028 * \\
(.014)\end{array}$ & $\begin{array}{l}-.008 \\
(.007)\end{array}$ & $\begin{array}{c}-.037 * * \\
(.002)\end{array}$ & $\begin{array}{l}-.022 \\
(.024)\end{array}$ \\
\hline Pop $_{\text {imp }}$ & $\begin{array}{c}-.020 * * \\
(.002)\end{array}$ & $\begin{array}{l}-.012 \\
(.013)\end{array}$ & $\begin{array}{c}.005 \\
(.007)\end{array}$ & $\begin{array}{c}-.024 * * \\
(.002)\end{array}$ & $\begin{array}{l}-.018 \\
(.011)\end{array}$ \\
\hline Log Distance & $\begin{array}{l}.038 * * \\
(.004)\end{array}$ & $\begin{array}{l}.037 * * \\
(.004)\end{array}$ & . & $\begin{array}{l}.045^{* *} \\
(.006)\end{array}$ & $\begin{array}{l}.037 * * \\
(.015)\end{array}$ \\
\hline Language & $\begin{array}{l}-.007 \\
(.005)\end{array}$ & $\begin{array}{l}-.013 * \\
(.006)\end{array}$ & . & $\begin{array}{l}-.011 \\
(.010)\end{array}$ & $\begin{array}{l}-.009 \\
(.008)\end{array}$ \\
\hline Border & $\begin{array}{l}-.018 * \\
(.008)\end{array}$ & $\begin{array}{c}-.027 * * \\
(.010)\end{array}$ & . & $\begin{array}{l}-.018 \\
(.023)\end{array}$ & $\begin{array}{l}-.017 \\
(.019)\end{array}$ \\
\hline Landlocked & $\begin{array}{l}.021 * * \\
(.006)\end{array}$ & $\begin{array}{l}-.112 \\
(.081)\end{array}$ & . & $\begin{array}{l}.034 * * \\
(.007)\end{array}$ & $\begin{array}{c}.005 \\
(.061)\end{array}$ \\
\hline Island & $\begin{array}{c}.006 \\
(.005)\end{array}$ & $\begin{array}{c}.002 \\
(.081)\end{array}$ & . & $\begin{array}{c}.009 \\
(.008)\end{array}$ & $\begin{array}{c}.006 \\
(.033)\end{array}$ \\
\hline Product area & $\begin{array}{l}.005 * * \\
(.001)\end{array}$ & $\begin{array}{c}.007 \\
(.009)\end{array}$ & . & $\begin{array}{l}.006 * * \\
(.001)\end{array}$ & $\begin{array}{c}.005 \\
(.004)\end{array}$ \\
\hline Com. colonizer & $\begin{array}{c}-.061 * * \\
(.008)\end{array}$ & $\begin{array}{c}-.065^{* *} \\
(.010)\end{array}$ & . & $\begin{array}{c}-.067 * * \\
(.013)\end{array}$ & $\begin{array}{c}-.057 * * \\
(.024)\end{array}$ \\
\hline Ever colony & $\begin{array}{l}-.008 \\
(.007)\end{array}$ & $\begin{array}{l}-.019 * \\
(.008)\end{array}$ & . & $\begin{array}{l}-.013 \\
(.029)\end{array}$ & $\begin{array}{l}-.011 \\
(.022)\end{array}$ \\
\hline
\end{tabular}

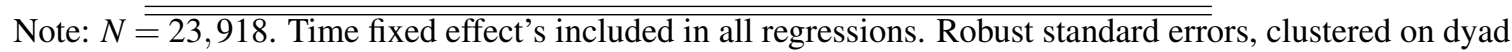
appear in parentheses; ** indicates $p<.01 ; *$ indicates $p<.05$. 
Table 2: Robustness Models for International Political Determinants of Export Volatility, 19501999

\begin{tabular}{|c|c|c|c|c|c|}
\hline & Pooled & $\begin{array}{l}\text { Fixed Exp., } \\
\text { Imp. effects }\end{array}$ & $\begin{array}{l}\text { Dyad } \\
\text { FE's }\end{array}$ & $\begin{array}{l}\text { Dyad } \\
\text { RE's }\end{array}$ & BMA \\
\hline \multicolumn{6}{|c|}{ Robustness Test 1: Controls for Alliance \& Diplomatic Volatility (Exp. \& Imp.) } \\
\hline Alliance & $\begin{array}{l}-.015^{*} \\
(.006)\end{array}$ & $\begin{array}{c}-.028 * * \\
(.008)\end{array}$ & $\begin{array}{c}-.014 * * \\
(.005)\end{array}$ & $\begin{array}{l}-.023^{*} \\
(.010)\end{array}$ & $\begin{array}{c}-.021 * * \\
(.010)\end{array}$ \\
\hline Diplomacyexp $_{\text {exp }}$ & $\begin{array}{c}-.028 * * \\
(.005)\end{array}$ & $\begin{array}{c}-.032 * * \\
(.006)\end{array}$ & $\begin{array}{c}-.013 * * \\
(.005)\end{array}$ & $\begin{array}{c}-.031 * * \\
(.007)\end{array}$ & $\begin{array}{c}-.028 * * \\
(.009)\end{array}$ \\
\hline \multicolumn{6}{|c|}{ Robustness Test 2: Controls for Regime Transitions (Exp. \& Imp.) } \\
\hline Alliance & $\begin{array}{c}-.016 * * \\
(.006)\end{array}$ & $\begin{array}{c}-.038^{* *} * \\
(.008)\end{array}$ & $\begin{array}{c}-.015^{* *} \\
(.005)\end{array}$ & $\begin{array}{l}-.022 * \\
(.010)\end{array}$ & $\begin{array}{c}-.022 * * \\
(.011)\end{array}$ \\
\hline Diplomacy $_{\exp }$ & $\begin{array}{c}-.028 * * \\
(.005)\end{array}$ & $\begin{array}{c}-.032 * * \\
(.006)\end{array}$ & $\begin{array}{c}-.020 * * \\
(.004)\end{array}$ & $\begin{array}{c}-.029 * * \\
(.007)\end{array}$ & $\begin{array}{c}-.028 * * \\
(.007)\end{array}$ \\
\hline \multicolumn{6}{|c|}{ Robustness Test 3: Controls for Monadic Intra or Inter-State Conflict (Exp. \& Imp.) } \\
\hline Alliance & $\begin{array}{c}-.020 * * \\
(.006)\end{array}$ & $\begin{array}{c}-.040 * * \\
(.009)\end{array}$ & $\begin{array}{c}-.015^{* *} \\
(.005)\end{array}$ & $\begin{array}{l}-.024 * \\
(.010)\end{array}$ & $\begin{array}{c}-.026 * * \\
(.011)\end{array}$ \\
\hline Diplomacyexp $_{\exp }$ & $\begin{array}{c}-.031 * * \\
(.005)\end{array}$ & $\begin{array}{c}-.032 * * \\
(.006)\end{array}$ & $\begin{array}{c}-.021 * * \\
(.005)\end{array}$ & $\begin{array}{c}-.030 * * \\
(.007)\end{array}$ & $\begin{array}{c}-.030 * * \\
(.007)\end{array}$ \\
\hline \multicolumn{6}{|c|}{ Robustness Test 4: Controls for Monadic Mean-Democracy Years (Exp. \& Imp.) } \\
\hline Alliance & $\begin{array}{c}-.018 * * \\
(.006)\end{array}$ & $\begin{array}{c}-.038 * * \\
(.009)\end{array}$ & $\begin{array}{c}-.015^{* *} \\
(.005)\end{array}$ & $\begin{array}{l}-.023 * \\
(.010)\end{array}$ & $\begin{array}{c}-.023 * * \\
(.011)\end{array}$ \\
\hline Diplomacyexp $_{\text {exp }}$ & $\begin{array}{c}-.030 * * \\
(.005)\end{array}$ & $\begin{array}{c}-.034 * * \\
(.006)\end{array}$ & $\begin{array}{c}-.020 * * \\
(.004)\end{array}$ & $\begin{array}{c}-.030 * * \\
(.007)\end{array}$ & $\begin{array}{c}-.029 * * \\
(.007)\end{array}$ \\
\hline \\
\hline Alliance & $\begin{array}{c}-.009 * * \\
(.003)\end{array}$ & $\begin{array}{c}-.014 * * \\
(.004)\end{array}$ & $\begin{array}{c}-.013 * * \\
(.004)\end{array}$ & $\begin{array}{c}-.012 * * \\
(.004)\end{array}$ & $\begin{array}{c}-.011 * * \\
(.004)\end{array}$ \\
\hline Diplomacy $_{\exp }$ & $\begin{array}{c}-.025 * * \\
(.003)\end{array}$ & $\begin{array}{c}-.030 * * \\
(.003)\end{array}$ & $\begin{array}{c}-.018 * * \\
(.003)\end{array}$ & $\begin{array}{c}-.024 * * \\
(.003)\end{array}$ & $\begin{array}{c}-.026 * * \\
(.004)\end{array}$ \\
\hline \multicolumn{6}{|c|}{ Robustness Test 6: Export Volatility and Regressors Calculated over 10 Year Periods } \\
\hline Alliance & $\begin{array}{l}-.005 \\
(.004)\end{array}$ & $\begin{array}{c}-.016 * * \\
(.005)\end{array}$ & $\begin{array}{l}-.001 \\
(.004)\end{array}$ & $\begin{array}{l}-.009 \\
(.006)\end{array}$ & $\begin{array}{l}-.001 \\
(.006)\end{array}$ \\
\hline Diplomacy $_{\exp }$ & $\begin{array}{c}-.024 * * \\
(.003)\end{array}$ & $\begin{array}{c}-.026 * * \\
(.003)\end{array}$ & $\begin{array}{c}-.013 * * \\
(.002)\end{array}$ & $\begin{array}{c}-.016 * * \\
(.004)\end{array}$ & $\begin{array}{c}-.019 * * \\
(.005)\end{array}$ \\
\hline \multicolumn{6}{|c|}{ Robustness Test 7: Export Volatility and Regressors Calculated over 5 Year Periods } \\
\hline Alliance & $\begin{array}{l}-.005 \\
(.003)\end{array}$ & $\begin{array}{c}-.013 * * \\
(.004)\end{array}$ & $\begin{array}{l}-.005 \\
(.003)\end{array}$ & $\begin{array}{c}-.011 * * \\
(.004)\end{array}$ & $\begin{array}{l}-.008 \\
(.006)\end{array}$ \\
\hline Diplomacy $_{\text {exp }}$ & $\begin{array}{c}-.016 * * \\
(.002)\end{array}$ & $\begin{array}{c}-.017 * * \\
(.002)\end{array}$ & $\begin{array}{c}-.011 * * \\
(.002)\end{array}$ & $\begin{array}{c}-.010 * * \\
(.003)\end{array}$ & $\begin{array}{l}-.017 \\
(.002)\end{array}$ \\
\hline
\end{tabular}

Note: Time fixed-effects included in all regressions. Robust standard errors, clustered on dyad appear in parentheses; ** indicates $p<.01$; * indicates $p<.05$. 